\title{
ANALISIS EFISIENSI INDUSTRI KREATIF UNGGULAN KOTA BANDUNG DENGAN PENDEKATAN DATA ENVELOPMENT ANALYSIS
}

\author{
Riza Fathoni Ishak ${ }^{1)}$, Somadi ${ }^{2)}$ \\ Program Studi Teknik Industri, Fakultas Teknik, Universitas Pasundan \\ email: rizafathoni40@yahoo.com \\ Program Studi D4 Logistik Bisnis, Politeknik Pos Indonesia \\ email: somadi@poltekpos.ac.id
}

\begin{abstract}
ABSTRAK
Kota Bandung merupakan salah satu kota yang menghasilkan produk kreatif yang sudah dikenal secara nasional maupun internasional. Namun dalam perkembangannya, industri kreatif Kota Bandung menghadapi berbagai permasalahan dan tantangan, sehingga dapat mengganggu keberlangsungan usaha. Untuk itu tujuan penelitian adalah menentukan industri kreatif unggulan yang efisien di Kota Bandung. Rencana pemecahan masalah menggunakan pendekatan DEA (Data Envelopment Analysis). Jenis industri kreatif unggulan sebagai decision making unit, asset dan tenaga kerja sebagai variabel input serta omset sebagai variabel output. Berdasarkan hasil pengolahan data, di peroleh informasi bahwa industri musik dan industri fesyen menjadi industri kreatif yang paling efisien karena hasil projected value omset nilainya sama dengan actual value omset dengan nilai efisiensi $100 \%$. Sehingga dengan kapasitas tenaga kerja yang ada dan asset yang dimiliki mampu memberikan produktifitas yang optimal. Berbeda dengan industri kreatif lainnya, mayoritas tingkat efisiensinya masih rendah sehingga dikategorikan rentan untuk kelangsungan bisnis usaha bila tidak dilakukan perubahan dan perbaikan dalam aspek input produksi.
\end{abstract}

Kata Kunci : Industri Kreatif, Data Envelopment Analysis (DEA), Efisiensi

\section{ABSTRACT}

The city of Bandung is one of the cities that produces creative products that have been known nationally and internationally. But in its development, the creative industry of Bandung City faces various problems and challenges, so that it can disrupt business continuity. For this reason, the purpose of the research is to determine the superior creative industries that are efficient in the city of Bandung. The problem solving plan uses the Data Envelopment Analysis (DEA) approach. The type of superior creative industry as a decision making unit, assets and labor as input variables and turnover as output variables. Based on the results of data processing, information was obtained that the music industry and fashion industry were the most efficient creative industries because the results of the projected value of turnover were the same as the actual value turnover with a value of $100 \%$ efficiency. So that with the existing workforce capacity and assets that are owned are able to provide optimal productivity. In contrast to other creative industries, the majority of efficiency levels are still low so it is categorized as vulnerable to the continuity of business if there are no changes and improvements in aspects of production inputs.

Keywords : Creative Industry, Data Envelopment Analysis (DEA), Efficiency

\section{PENDAHULUAN}

Perkembangan bisnis telah banyak mengalami perubahan dalam bentuk dan modelnya. Hal ini sangat dipengaruhi oleh perkembangan zaman terkait teknologi, perubahan selera konsumen, dan persaingan usaha. Banyak usaha yang relatif sederhana dan home made menjadi trend setter, dimana usaha tidak harus berbasis modal dan bangunan yang besar, namun usaha tersebut mampu menarik banyak peminat dan permintaan terus mengalami peningkatan. Perubahan sistem perdagangan dari offline menjadi online menjadi tantangan bagi pelaku usaha dengan beberapa aspek kemudahan dalam 
transaksi dan kecepatan informasi sangat mendukung kepada pelaksanaan bisnis. Dari sisi konsumen khususnya daerah perkotaan semakin membutuhkan pelayanan usaha yang tepat waktu, biaya yang minimum, dan semakin customized.

Berbagai kondisi diatas menjadikan peluang bagi masyarakat untuk mendirikan usaha guna memenuhi kebutuhan konsumen melalui kreatifitas dan inovasi yang diciptakan oleh pelaku usaha baik dari sisi produk, pelayanan, pemasaran, pemanfaatkan lokasi dan wilayah, serta penggunaan teknologi IT. Usaha yang menggunakan kreatifitas dan inovasi sering disebut dengan industri kreatif.

Menurut Dzikri Prakasa Putra, dkk (2013), menyatakan bahwa industri kreatif adalah industri yang berasal dari pemanfaatan kreativitas, keterampilan serta bakat individu untuk menciptakan kesejahteraan serta lapangan pekerjaan dengan menghasilkan dan mengeksploitasi daya kreasi dan daya cipta individu tersebut. Industri kreatif dipandang semakin penting dalam mendukung kesejahteraan dalam perekonomian. Kementerian Perdagangan Republik Indonesia dalam Dina Mellita dan Deni Erlansyah (2014) membagi industri kreatif di Indonesia menjadi 14 subsektor yakni periklanan, arsitektur, pasar barang seni, kerajinan, desain, fesyen, video, film dan fotografi, permainan interaktif, musik, seni pertunjukan, penerbitan dan percetakan, layanan komputer dan peranti lunak, televisi dan radio, serta riset dan pengembangan.

Perkembangan industri kreatif cukup pesat dan mampu memberikan kontribusi pada pertumbuhan ekonomi nasional. Berdasarkan data dari Bekraf dalam Nusarina Yuliastuti (2019), bahwa kinerja ekonomi kreatif naik sekitar Rp. 100 triliun pada Tahun 2018 dan kontribusi pada produk domestik bruto (PDB) lebih tinggi daripada pertumbuhan PDB itu sendiri atau sekitar Rp. 1.105 triliun. Peningkatan kontribusi industri kreatif tidak terlepas dari dukungan digitalisasi, kemudahan akses pasar dan permodalan, serta kondisi infrastruktur yang semakin baik.

Saat ini, Indonesia belum masuk ke dalam kelompok negara industri maju di dunia karena masih banyak aspek yang menjadi persoalan dalam mengembangkan sektor industri nasional, salah satunya adalah masih minimnya jumlah pelaku usaha pada sektor industri terutama industri kreatif. Industri kreatif cenderung berkembang di daerah perkotaan dibandingkan di perdesaan, hal ini disebabkan karena kemampuan sumber daya manusia kreatif lebih banyak tumbuh di kota dengan dasar-dasar pengetahuan yang lebih tinggi dibanding daerah pedesaan. Sumber utama industri kreatif adalah inovasi dari pelaku usaha yang mampu memberikan keunikan, ciri khas yang kental, dengan produk yang lebih spesifik dan muatan teknologi IT yang kuat.

Kota Bandung menjadi salah satu daerah yang mempunyai potensi industri kreatif yang besar dalam posisi nasional, dimana Kota Bandung dikenal dengan salah satu pusat fesyen, produk film, musik, desain, karya seni dan inovasi dalam bidang aplikasi IT. Dengan didominasi oleh penduduk usia muda, Kota Bandung memiliki beragam komunitas yang kreatif dan produktif. Dalam 10 tahun terakhir, industri kreatif di Kota Bandung menunjukkan perkembangan signifikan dan mempengaruhi tren anak muda. Kota Bandung menjadi salah satu kota kreatif terbaik di Indonesia dan sektor industri kreatif menjadi penyumbang terbesar terhadap pendapatan dan perekonomian daerah.

Keberlangsungan industri kreatif di Kota Bandung menjadi isu penting saat ini, sehingga kegiatan usaha perlu mempertimbangkan aspek efisiensi dalam bisnis. Apalagi kini tingkat persaingan semakin tinggi, harga produk impor lebih murah dan membanjiri pasar dalam negeri, serta terus meningkatnya harga yang berdampak terhadap tingginya biaya produksi.

Dengan diperolehnya tingkat efisiensi pada masing-masing industri kreatif di Kota Bandung, diharapkan dapat memberikan gambaran kepada pelaku usaha agar memperhatikan kualitas input produksi yang meliputi efisiensi asset dan tenaga kerja yang mampu menghasilkan produktifitas atau omset penjualan secara optimal, dan mampu memberikan masukkan untuk pengambilan kebijakan pemerintah daerah untuk melakukan pembinaan kepada industri kreatif yang bertujuan untuk meningkatkan kompetensi pelaku usaha dan tenaga kerja dalam kemampuan proses produksi, manajerial, peningkatan seni dan mutu desain produk agar memberikan nilai tambah yang tinggi dan mampu menghasilkan omset yang besar.

\section{Rumusan Masalah}

Berdasarkan latar belakang di atas, maka rumusan masalah dalam penelitian ini adalah bagaimana efisiensi industri kreatif unggulan Kota Bandung dengan pendekatan DEA (Data Envelopment Analysis)?. 


\section{Tujuan Penelitian dan Rencana Pemecahan Masalah}

Berdasarkan kepada perumusan permasalahan diatas, maka tujuan penelitian adalah untuk mengetahui, menganalisis, dan mengkaji efisiensi industri kreatif unggulan di Kota Bandung dengan pendekatan DEA (Data Envelopment Analysis). Adapun rencana pemecahan masalah yang dilakukan melalui pendekatan DEA (Data Envelopment Analysis).

\section{Tinjauan Pustaka}

Industri kreatif menjadi salah satu fokus dalam suatu kebijakan pemerintah. Namun pemahaman terkait industri kreatif bukan apa yang pemerintah lakukan lebih kepada arti sesungguhnya industri kreatif, karena pada dasarnya industri kreatif merupakan bagian dari industri lain yang dikenali dan dipahami sebagai kreatifitasnya (Roodhouse, 2008). Higgs and Cunningham (2008:9), mendefiniskani industri kreatif sebagai industri yang memiliki originalitas dari kreatifitas individu, keahlian dan talenta yang berpotensi peningkatan kesejahteraan dan penciptaan pekerjaan melalui generasi dengan eksploitasi intelektualitasnya. Sedangkan menurut Dina Mellita dan Deni Erlansyah (2014), industri kreatif merupakan industri yang berasal dari pemanfaatan kreatifitas, keterampilan serta bakat individu untuk menciptakan kesejahteraan serta lapangan pekerjaan dengan menghasilkan dan mengeksploitasi daya kreasi dan daya cipta individu.

Menurut Higgs and Cunningham (2008), menjelaskan sebuah rantai nilai industri kreatif adalah : 1. Creation $>2$. Making $>3$. Dissemination $>4$. Exhibition/Reception $>5$. Archiving/Preservation $>$ 6. Education/Understanding.

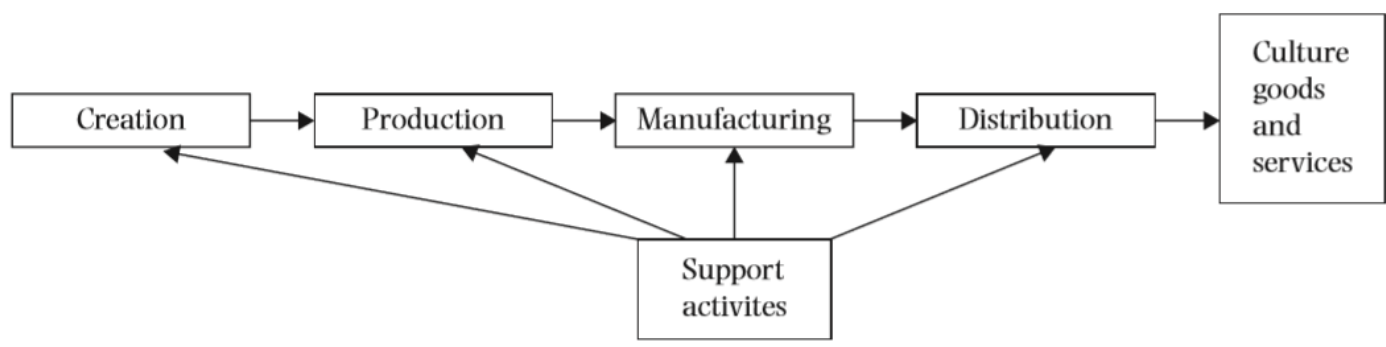

Sumber : Higgs and Cunningham (2008)

Gambar 1. Rantai Nilai Produksi Industri Kreatif

Kerangka di atas tidak menunjukkan perbedaan antara nilai aktivitas utama dalam rantai nilai dan dukungan infrastruktur, bahwa tidak perlu menguraikan masalah pelatihan dan peran pemerintah, dan asosiasi bukan bagian dari rantai nilai industri kreatif tetapi secara otomatis akan menjadi kegiatan pendukung. lain yaitu:

Berdasarkan konsep tentang industri kreatif, maka dapat diambil beberapa poin penting, antara

1. Sumber industri kreatif diawali dengan adanya ide inovatif yang di implementasikan dalam bentuk produk/jasa .

2. Ide inovatif muncul disebabkan oleh adanya talenta dan keahlian individu.

3. Industri kreatif lebih banyak dikonotasikan dengan produk - produk yang bersifat seni, budaya, dan teknologi komputasi (IT).

4. Kesimpulan peneliti bahwa kategori kelompok industri kreatif itu lebih proporsi nilai inovasi kreatif yang tinggi, dan dominan, bukan kepada mobilisasi produksinya.

Di Indonesia, industri kreatif didefinisikan sebagai industri yang berasal dari pemanfaatan kreativitas, keterampilan serta bakat individu. Fokus pemerintah Indonesia terhadap industri kreatif dimulai tahun 2006. Ada 14 sub sektor industri kreatif, antara lain yaitu :

Tabel 1. Pengelompokkan Industri Kreatif

\begin{tabular}{|c|c|l|}
\hline No & $\begin{array}{c}\text { Jenis Industri } \\
\text { Kreatif }\end{array}$ & \multicolumn{1}{c|}{ Kegiatan } \\
\hline 1 & Periklanan & $\begin{array}{l}\text { Kegiatan kreatif yang berkaitan dengan kreasi dan produksi iklan, } \\
\text { antara lain: riset pasar, perencanaan komunikasi iklan, iklan luar ruang, } \\
\text { produksi material iklan, promosi, kampanye relasi publik, tampilan } \\
\text { iklan di media cetak dan elektronik. }\end{array}$ \\
\hline
\end{tabular}




\begin{tabular}{|c|c|c|}
\hline No & $\begin{array}{l}\text { Jenis Industri } \\
\text { Kreatif }\end{array}$ & Kegiatan \\
\hline 2 & Arsitektur & $\begin{array}{l}\text { Kegiatan kreatif yang berkaitan dengan cetak biru bangunan dan } \\
\text { informasi produksi antara lain: arsitektur taman, perencanaan kota, } \\
\text { perencanaan biaya konstruksi, konservasi bangunan warisan, } \\
\text { dokumentasi lelang, dll. }\end{array}$ \\
\hline 3 & $\begin{array}{l}\text { Pasar seni dan } \\
\text { barang antik }\end{array}$ & $\begin{array}{l}\text { Kegiatan kreatif yang berkaitan dengan kreasi dan perdagangan, } \\
\text { pekerjaan, produk antik dan hiasan melalui lelang, galeri, toko, pasar } \\
\text { swalayan, dan internet. }\end{array}$ \\
\hline 4 & Kerajinan & $\begin{array}{l}\text { Kegiatan kreatif yang berkaitan dengan kreasi dan distribusi produk } \\
\text { kerajinan antara lain barang kerajinan yang terbuat dari: batu berharga, } \\
\text { aksesoris, pandai emas, perak, kayu, kaca, porselin, kain, marmer, } \\
\text { kapur, dan besi. }\end{array}$ \\
\hline 5 & Desain & $\begin{array}{l}\text { Kegiatan kreatif yang terkait dengan kreasi desain grafis, interior, } \\
\text { produk, industri, pengemasan, dan konsultasi identitas perusahaan. }\end{array}$ \\
\hline 6 & Desain Fesyen & $\begin{array}{l}\text { Kegiatan kreatif yang terkait dengan kreasi desain pakaian, desain alas } \\
\text { kaki, dan desain aksesoris mode lainnya, produksi pakaian mode dan } \\
\text { aksesorisnya, konsultansi lini produk fesyen, serta distribusi produk } \\
\text { fesyen. }\end{array}$ \\
\hline 7 & $\begin{array}{l}\text { Video, Film dan } \\
\text { Fotografi }\end{array}$ & $\begin{array}{l}\text { Kegiatan kreatif yang terkait dengan kreasi produksi video, film, dan } \\
\text { jasa fotografi, serta distribusi rekaman video, film. Termasuk } \\
\text { didalamnya penulisan skrip, dubbing film, sinematografi, sinetron, dan } \\
\text { eksibisi film. }\end{array}$ \\
\hline 8 & Permainan Interaktif & $\begin{array}{l}\text { Kegiatan kreatif yang berkaitan dengan kreasi, produksi, dan distribusi } \\
\text { permainan komputer dan video yang bersifat hiburan, ketangkasan, dan } \\
\text { edukasi. }\end{array}$ \\
\hline 9 & Musik & $\begin{array}{l}\text { Kegiatan kreatif yang berkaitan dengan kreasi, produksi, distribusi, dan } \\
\text { ritel rekaman suara, hak cipta rekaman, promosi musik, penulis lirik, } \\
\text { pencipta lagu atau musik, pertunjukan musik, penyanyi, dan komposisi } \\
\text { musik. }\end{array}$ \\
\hline 10 & Seni Pertunjukkan & $\begin{array}{l}\text { Kegiatan kreatif yang berkaitan dengan usaha yang berkaitan dengan } \\
\text { pengembangan konten, produksi pertunjukan, pertunjukan balet, tarian } \\
\text { tradisional, tarian kontemporer, drama, musik tradisional, musik teater, } \\
\text { opera, termasuk tur musik etnik, desain dan pembuatan busana } \\
\text { pertunjukan, tata panggung, dan tata pencahayaan. }\end{array}$ \\
\hline 11 & $\begin{array}{l}\text { Penerbitan dan } \\
\text { Percetakan }\end{array}$ & $\begin{array}{l}\text { Kegiatan kreatif yang terkait dengan dengan penulisan konten dan } \\
\text { penerbitan buku, jurnal, koran, majalah, tabloid, dan konten digital } \\
\text { serta kegiatan kantor berita. }\end{array}$ \\
\hline 12 & $\begin{array}{l}\text { Layanan Komputer } \\
\text { dan Piranti Lunak }\end{array}$ & $\begin{array}{l}\text { Kegiatan kreatif yang terkait dengan pengembangan teknologi } \\
\text { informasi termasuk jasa layanan komputer, pengembangan piranti } \\
\text { lunak, integrasi sistem, desain dan analisis sistem, desain arsitektur } \\
\text { piranti lunak, desain prasarana piranti lunak \& piranti keras, serta } \\
\text { desain portal. }\end{array}$ \\
\hline 13 & Televisi dan Radio & $\begin{array}{l}\text { Kegiatan kreatif yang berkaitan dengan usaha kreasi, produksi dan } \\
\text { pengemasan, penyiaran, dan transmisi televisi dan radio. }\end{array}$ \\
\hline 14 & $\begin{array}{l}\text { Riset dan } \\
\text { Pengembangan }\end{array}$ & $\begin{array}{l}\text { Kegiatan kreatif yang terkati dengan usaha inovatif yang menawarkan } \\
\text { penemuan ilmu dan teknologi dan penerapan ilmu dan pengetahuan } \\
\text { tersebut untuk perbaikan produk dan kreasi produk baru, proses baru, } \\
\text { material baru, alat baru, metode baru, dan teknologi baru yang dapat } \\
\text { memenuhi kebutuhan pasar. }\end{array}$ \\
\hline
\end{tabular}

Sumber : Dina Mellita dan Deni Erlansyah, 2014

Dengan ditunjuknya Kementerian Perdagangan, Kementerian Perindustrian, dan Kementerian Pariwisata untuk mengawali industri kreatif, hal tersebut memberikan harapan baru bagi kalangan 
pelaku industri. Pertama, soal kendala pembajakan karya. Dalam hal ini, rendahnya daya beli masyarakat membuat pembajakan atas karya-karya kreatif semakin marak. Akibatnya, ide-ide kreatif sering kali pupus yang pada akhirnya menyebabkan penurunan pada kreativitas. Kedua, soal kendala pembiayaan. Dengan belum diakuinya aktivitas ekonomi kreatif, pihak perbankan belum menyediakan pembiayaan untuk aktivitas industri ini. Minimnya modal secara tidak langsung akan memangkas kreativitas, karena pelaku industri ini akan bekerja berdasarkan pesanan saja, bukan dari gagasan sendiri. Ketiga, hal ini berkaitan dengan peningkatan kemampuan sumber daya manusia. Dalam hal ini, pendidikan di bidang industri kreatif masih kurang. Padahal, kontribusi ekonomi kreatif dalam perekonomian nasionnal terus naik. Peningkatan itu tentunya akan membutuhkan tenaga-tenaga kreatif, inovatif dan andal. Dengan demikian, tidak mungkin tenaga-tenaga kreatif terbentuk tanpa adanya jenjang pendidikan di bidang industri kreatif (Dina Mellita dan Deni Erlansyah, 2014).

\subsection{Data Envelopment Analysis (DEA)}

Menurut Andrew Filardo, dkk (2017), DEA adalah sebuah teknik pemrograman matematis berdasarkan pada linier programming yang digunakan untuk mengevaluasi efisiensi dari suatu unit pengambilan keputusan (unit kerja) yang bertanggung jawab menggunakan sejumlah input untuk memperoleh suatu output yang ditargetkan. Metode DEA diciptakan sebagai alat evaluasi kinerja suatu aktivitas di sebuah unit entitas (organisasi) yang selanjutnya disebut Decision Making Unit (DMU). Secara sederhana, pengukuran ini dinyatakan dengan rasio: output/input, yang merupakan suatu pengukuran efisiensi atau produktivitas Dalam pengukuran efisiensi dengan menggunakan DEA terdapat dua model yang sering digunakan, yaitu Constant Return to Scale (CRS) dan Variable Return to Scale (VRS).

Menurut Charnes, Cooper, dan Rhodes dalam Andrew Filardo, dkk (2017), model ini dapat menunjukkan technical efficiency secara keseluruhan atau nilai dari profit efficiency untuk setiap DMU. Pengukuran berorientasi input menunjukkan sejumlah input dapat dikurangi secara proporsional tanpa mengubah jumlah output yang dihasilkan. Dengan menggunakan model berorientasi input, maka model tersebut akan menghitung pengurangan input yang diperlukan untuk menghasilkan kinerja yang efisien dengan output yang tetap. Fethi \& Pasiouras (2010) dalam Andrew Filardo, dkk (2017) mengungkapkan bahwa industri perbankan yang menggunakan pendekatan berorientasi input memiliki asumsi bahwa manajer bank akan memiliki pengawasan atau kontrol yang lebih tinggi atas input (seperti: bebanbeban, karyawan, dan lain-lain) dibandingkan output (seperti: kredit, pendapatan, dan lain-lain). Beberapa studi cenderung memilih pendekatan berorientasi input karena jumlah input menjadi keputusan utama dalam pengambilan variabel, walaupun alasan ini tidak berlaku untuk semua industri. Casu, B., \& Molyneux, P. (2003) dalam Andrew Filardo, dkk (2017).

Dengan demikian, berdasarkan hubungan antara variabel input dengan outputnya yaitu model CRS (Constant Returns To Scale) dan model VRS (Variable Returns To Scale), bahwa model dengan kondisi CRS mengindikasikan bahwa penambahan terhadap faktor produksi (input), tidak akan memberikan dampak pada tambahan produksi (output). Sedangkan model dengan kondisi VRS akan memperlihatkan bahwa penambahan sejumlah faktor produksi (input) akan memberikan peningkatan ataupun penurunan kapasitas produksi (output).

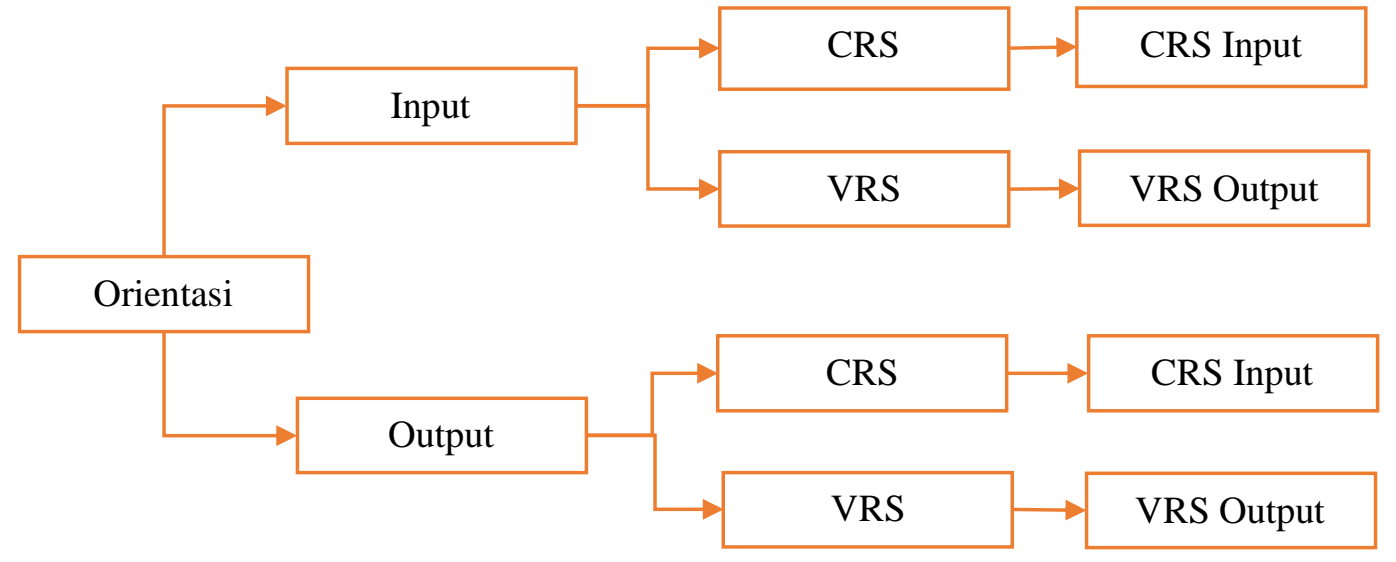

Sumber : Yasar A. Ozcan (2011) dalam Akbar Gunawan, dkk (2017) http://ejurnal.poltekpos.ac.id/index.php/competitive | 5 
Gambar 2. Pengklasifikasian Model DEA

\section{Kerangka Penelitian}

Berdasarkan teori dan penelitian-penelitian yang telah dilakukan, maka dapat dibuat suatu kerangka penelitian yang dapat dilihat pada gambar berikut ini.

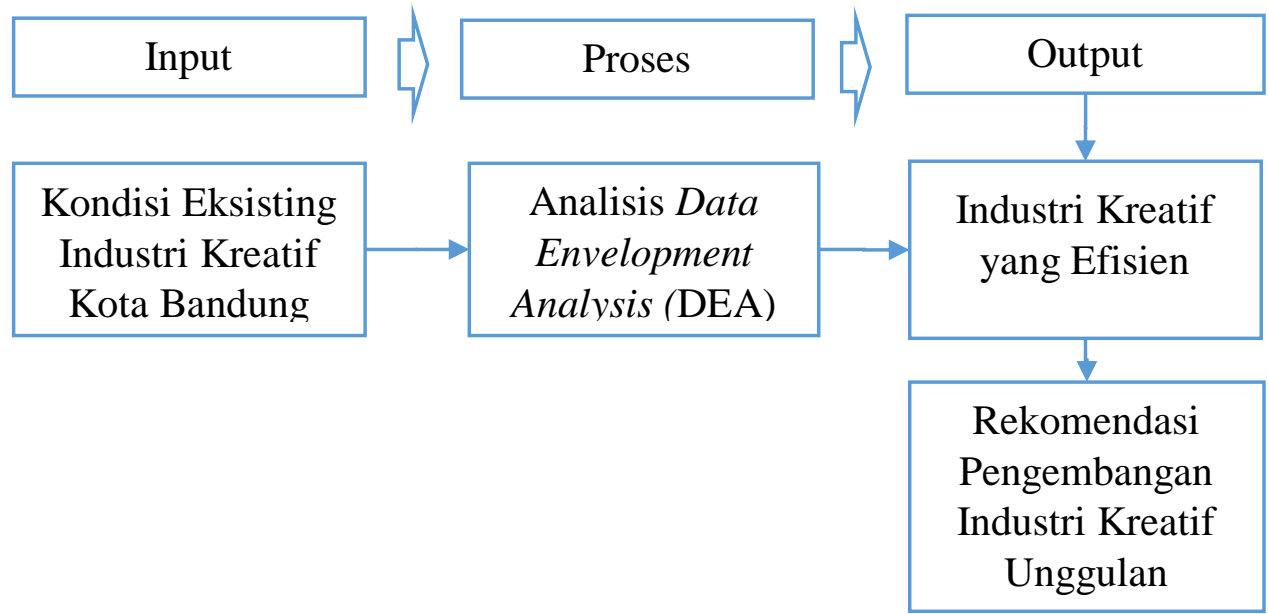

Sumber : Hasil Analisis, 2019

Gambar 3. Kerangka penelitian

Untuk pengambilan data lebih difokuskan kepada kondisi eksisting industri kreatif Kota Bandung meliputi jumlah asset yang digunakan, jumlah tenaga kerja yang terlibat, dan besaran omset penjualan yang dihasilkan. Dengan demikian data primer yang menjadi sumber data utama dalam penelitian, kemudian dibuatkan pemodelan kaitan antara variabel input dan output sesuai dengan model DEA untuk menghasilkan industri kreatif unggulan yang efisien di Kota Bandung.

\section{METODOLOGI PENELITIAN}

Penelitian ini menggunakan metoda kuantitatif, dan sumber data berasal dari data primer yang merupakan hasil penyebaran kuesioner kepada pelaku industri kreatif di Kota Bandung. Adapun langkah-langkah dalam penelitian yang dilakukan meliputi :

1) Identifikasi Permasalahan

Sebagai dasar dalam memulai penelitian adalah adanya kejelasan dalam penetapan masalah yang akan diteliti dari fenomena yang menjadi isu penting, khususnya dalam penelitian ini adalah mengenai efisiensi industri kreatif saat ini di Kota Bandung.

2) Pengumpulan Data

Jenis data yang digunakan dalam penelitian ini merupakan data primer yang berasal dari hasil wawancara dengan responden, dalam hal ini adalah para pelaku usaha industri kreatif unggulan di Kota Bandung dan Dinas Kebudayaan dan Parwisata Kota Bandung. Alasan menggunakan data primer disebabkan karena data sekunder yang tersedia saat ini masih menggunakan data yang lama dan masih banyak kesalahan dalam data tersebut sehingga peneliti disarankan oleh Dinas Kebudayaan dan Parwisata Kota Bandung untuk melakukan pembaharuan data kondisi industri kreatif unggulan di Kota Bandung yang sesuai dalam kebutuhan penelitian.

Tahapan pertama dalam pengumpulan data yakni melakukan koordinasi dan konfirmasi dengan pihak Dinas Kebudayaan dan Parwisata Kota Bandung untuk mendapatkan gambaran umum dan permasalahan mengenai industri kreatif di Kota Bandung saat ini, kemudian dilanjutkan dengan tahap penyebaran kuesioner ke responden yakni para pelaku usaha industri kreatif unggulan di Kota Bandung guna mendapatkan data yang diperlukan dalam penelitian ini. Pendekatan pengambilan sampel dalam penelitian ini menggunakan cluster sampling yang didasarkan kepada setiap region kecamatan, dan ruang lingkup pengambilan data primer untuk sampel penelitian adalah semua industri kreatif yang ada di Kota Bandung berdasarkan kriteria yang sudah ditentukan. Banyaknya sampel yang diambil disesuaikan dengan hasil penelusuran langsung ke lapangan, hal ini disebabkan karena tidak berbasis 
data populasi yang jelas sehingga industri yang dikategorikan belum pasti jumlahnya dan perlu penelusuran langsung.

3) Pengolahan Data

Tahapan selanjutnya yaitu melakukan pengolahan data. Adapun langkah-langkah pengolahan data dengan menggunakan analisis DEA, yakni sebagai berikut :

1. Menentukan DMU (Decission Making Unit)

2. Menentukan Variabel Input dan Output

3. Menghitung Efisiensi DMU

Untuk menghitung efisiensi DMU di bantu dengan menggunakan software Frontier Versi 4.1. Software Frontier Versi 4.1 digunakan untuk mendapatkan estimasi maksimum likelihood dari suatu subset dari produksi frontier stokastik dan fungsi biaya yang telah diusulkan dalam literatur. Program ini dapat menampung data panel, waktu bervariasi dan efisiensi invariant, fungsi biaya dan produksi, dan bentuk-bentuk fungsional yang memiliki variabel dependen dalam satuan login atau asli. Program tidak dapat mengakomodasi distribusi eksponensial atau gamma, juga tidak dapat memperkirakan sistem persamaan. Frontier Versi 4.1 ditulis untuk mengestimasi model spesifikasi (Battese dan Coelli, 1995).

4) Analisis dan Pembahasan

Hasil pengolahan data yang diperoleh dengan menggunakan bantuan software, maka dilanjutkan dengan melakukan interpretasi hasil pengolahan data dengan diawal inisialisasi pada tahap decision making unit yaitu sebagai objek yang dikaji sebagai pemilihannya, proses penentuan variabel input dan output sehingga membentuk model DEA yang akan diolah datanya untuk mendapatkan angka efisiensi relatif dari variabel controllable dan uncontrollable dan pada saat menentukan tingkat efisiensi dari setiap decision making unit.

5) Kesimpulan

Tahap berikutnya yaitu mengambil kesimpulan dari tujuan yang diharapkan dalam penelitian ini yaitu menentukan industri kreatif unggulan di Kota Bandung yang efisien.

\section{HASIL DAN PEMBAHASAN}

Dalam melakukan analisis DEA (Data Envelopment Analysis), diperlukan langkah-langkah sebagai berikut :

\section{Menentukan DMU (Decision Making Unit)}

Decision Making Unit yakni unit yang akan dilakukan analisis, sehingga dalam penelitian ini yakni jenis industri kreatif di Kota Bandung yang akan dilakukan pengolahan dengan analisis DEA (Data Envelopment Analysis). Berikut ini adalah jumlah dan jenis industri kreatif Kota Bandung Tahun 2018, dimana terdapat 354 pelaku usaha yang tersebar dalam 12 jenis industri kreatif.

Tabel 2. Jenis Industri Kreatif Kota Bandung Tahun 2018

\begin{tabular}{|c|l|c|}
\hline No & \multicolumn{1}{|c|}{ Jenis Industri Kreatif } & Jumlah Industri (Unit) \\
\hline 1 & Periklanan & 2 \\
\hline 2 & Arsitekur & 7 \\
\hline 3 & Pasar Barang Seni & 8 \\
\hline 4 & Kerajinan & 89 \\
\hline 5 & Desain & 16 \\
\hline 6 & Fesyen & 188 \\
\hline 7 & Video, Film dan Fotografi & 11 \\
\hline 8 & Permainan Interaktif & 1 \\
\hline 9 & Musik & 14 \\
\hline 10 & Penerbitan dan Percetakan & 14 \\
\hline 11 & Televisi dan Radio $\quad$ Total & 1 \\
\hline 12 & Riset dan Pengembangan & 3 \\
\hline & \multicolumn{354}{c}{} \\
\hline
\end{tabular}


Sumber : Data Rekap dari Hasil Survey Primer, Diolah Tahun 2019

2. Menentukan Variabel Input dan Output

Pada dasarnya dalam menentukan variabel input dan output pada analisis DEA tidak ada konsensus secara baku. Menurut Alfonso dan Aubyn (2005) dalam Akbar Gunawan (2017), variabel input DEA adalah besarnya sumber daya yang digunakan untuk menghasilkan suatu output, dan pemilihan variabel input dan output dalam DEA sangat bergantung pada adanya ketersediaan data. Pada penelitian ini, variabel input yang digunakan dalam analisis DEA yakni jumlah asset dan jumlah tenaga kerja, sedangkan variabel output dalam penelitian ini yakni omset para pelaku industri kreatif di Kota Bandung. Berikut ini adalah kondisi variabel input dan output industri kreatif Kota Bandung.

Tabel 3. Input dan Output Industri kreatif Kota Bandung

\begin{tabular}{|c|l|c|c|r|}
\hline No & \multicolumn{1}{|c|}{ Jenis Industri Kreatif } & $\begin{array}{c}\text { Jumlah Asset } \\
(\mathbf{R p})\end{array}$ & $\begin{array}{c}\text { Jumlah Tenaga } \\
\text { Kerja (Orang) }\end{array}$ & $\begin{array}{c}\text { Omset } \\
(\mathbf{R p}) / \text { Hari }\end{array}$ \\
\hline 1 & Periklanan & 4.000 .000 .000 & 15 & 7.000 .000 \\
\hline 2 & Arsitekur & 1.752 .000 .000 & 62 & 64.793 .000 \\
\hline 3 & $\begin{array}{l}\text { Pasar Barang Seni dan Seni } \\
\text { Pertunjukkan }\end{array}$ & 20.608 .000 .000 & 23 & 20.100 .000 \\
\hline 4 & Kerajinan & 10.178 .000 .000 & 424 & 197.368 .000 \\
\hline 5 & Desain & 1.512 .000 .000 & 41 & 36.656 .000 \\
\hline 6 & Fesyen & 37.275 .050 .000 & 1.217 & 2.506 .731 .000 \\
\hline 7 & Video, Film dan Fotografi & 2.920 .000 .000 & 46 & 18.094 .000 \\
\hline 8 & Permainan Interaktif & 300.000 .000 & 3 & 278.000 \\
\hline 9 & Musik & 3.250 .000 .000 & 97 & 215.100 .000 \\
\hline 10 & Penerbitan dan Percetakan & 5.775 .000 .000 & 237 & 87.960 .000 \\
\hline 11 & Televisi dan Radio & 4.000 .000 .000 & 20 & 15.000 .000 \\
\hline 12 & Riset dan Pengembangan & 1.350 .000 .000 & 27 & 6.600 .000 \\
\hline & Total & $\mathbf{1 0 2 . 8 8 1 . 0 5 0 . 0 0 0}$ & $\mathbf{2 , 6 5 9}$ & $\mathbf{3 . 1 7 5 . 6 8 0 . 0 0 0}$ \\
\hline
\end{tabular}

Sumber : Rekap data Hasil Survey Primer, Diolah Tahun 2019

Dengan demikian, berdasarkan variabel output dan input yang sudah ditetapkan maka omset pada masing-masing jenis industri kreatif di Kota Bandung yang dipengaruhi oleh jumlah asset dan jumlah tenaga kerja. Berikut ini adalah alur hubungan variabel input dan output pada industri kreatif di Kota Bandung.

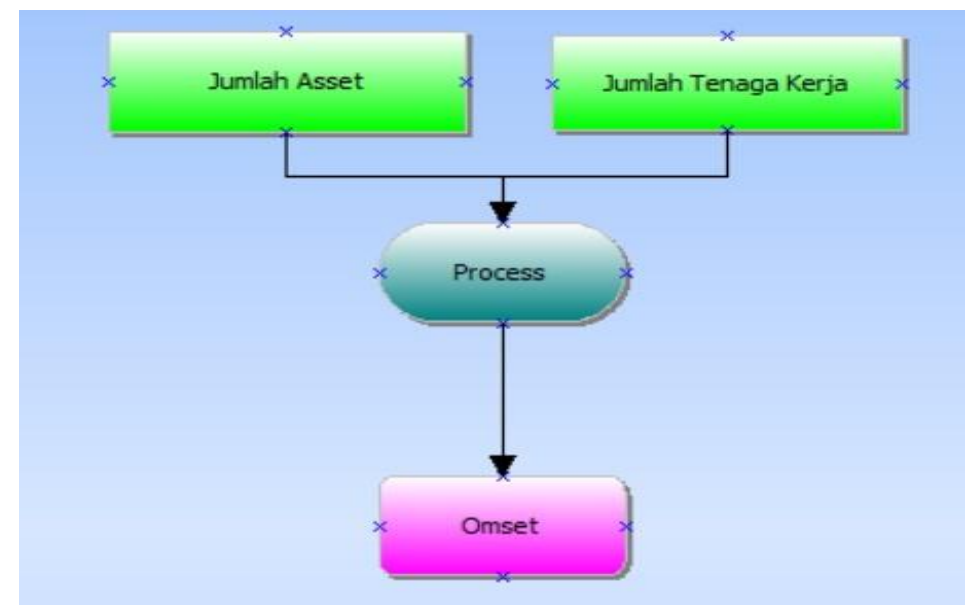

Sumber: Hasil Pengolahan Data dengan Software Frontier Versi 4.1, Tahun 2019 3. Menghitung Efisiensi DMU

Gambar 4. Diagram Proses Variabel Input dan Output 
Dalam melakukan perhitungan efisiensi pada setiap DMU penelitian ini akan dibantu dengan software Frontier Versi 4.1. untuk mempermudah dalam pengolahan data, yang dikhususkan untuk memecahkan persoalan pemilihan dengan analisis efisiensi dalam Model DEA (Data Envelopment Analysis). Berikut ini adalah hasil pengolahan data industri kreatif Kota Bandung dengan menggunakan software Frontier Versi 4.1.

Tabel 4. Hasil Pengolahan Data Industri Kreatif Kota Bandung

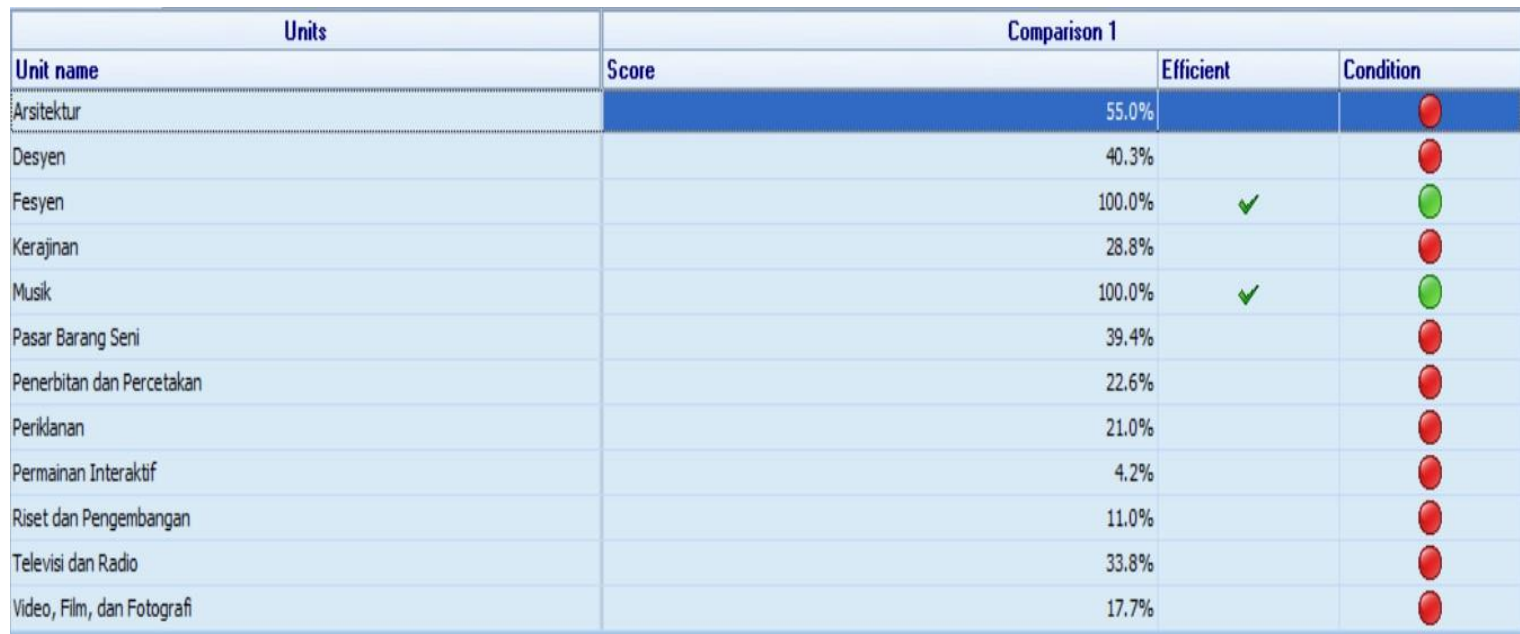

Sumber : Hasil Pengolahan Data dengan Software Frontier Versi 4.1, Tahun 2019

Berdasarkan tabel di atas, diperoleh hasil bahwa jenis industri kreatif di Kota Bandung yang memiliki tingkat efisiensi yaitu fesyen dan musik. Hal ini disebabkan karena fesyen dan musik memiliki tingkat efisiensi sebesar 100\%. Efisiensi masing-masing industri kreatif melalui variabel input dan output dikatakan efisien jika original value atau actual value $=$ projected value atau target value. Berikut ini adalah hasil pengolahan atau output CRS secara lebih lengkapnya pada masing-masing industri kreatif di Kota Bandung.

Tabel 5. Nilai Aktual dan Nilai Target Industri Kreatif Kota Bandung

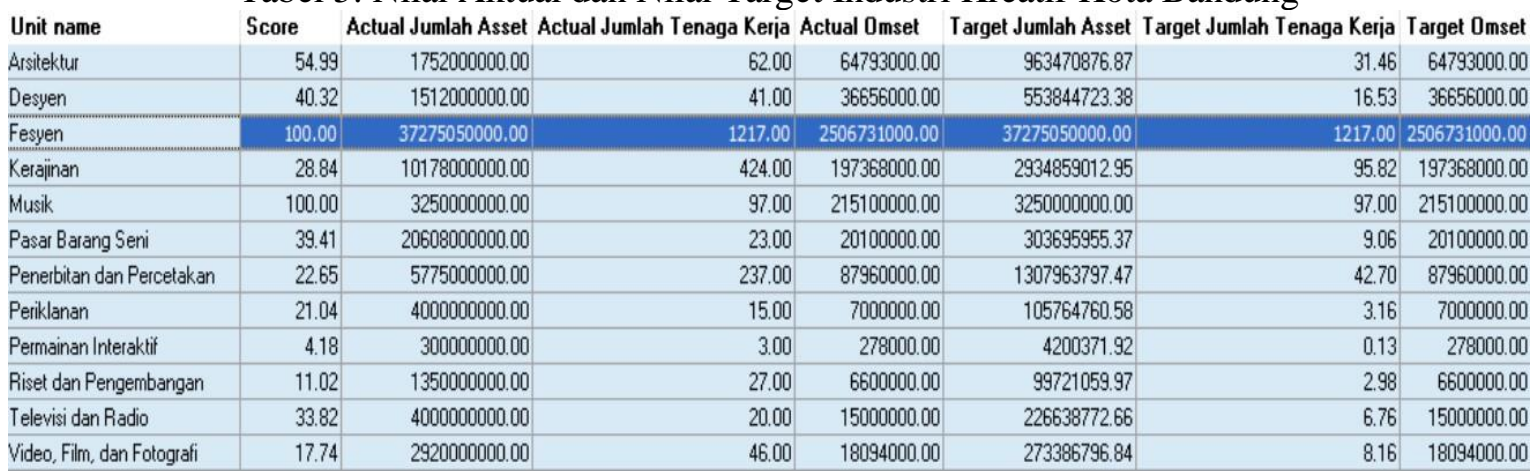

Sumber : Hasil Pengolahan Data dengan Software Frontier Versi 4.1, Tahun 2019

Berdasarkan tabel di atas, diperoleh informasi bahwa arsitektur, desyen, kerajinan, pasar barang seni, penerbitan dan percetakan, periklanan, permainan interaktif, riset dan pengembangan, televisi dan radio serta video, film, dan fotografi belum mencapai tingkat efisien karena pada variabel input maupun output belum memiliki nilai yang sama terkait nilai aktual dan nilai targetnya. Sedangkan fesyen dan musik sudah mencapai tingkat efisien karena pada variabel input mapun output memiliki nilai yang sama terkait dengan nilai aktual dan nilai targetnya.

Tabel 6. Nilai Differensiasi Jumlah Asset, Jumlah Tenaga Kerja dan Omset Industri Kreatif Kota Bandung 


\begin{tabular}{|l|r|r|r|r|r|}
\hline Unit name & Score & Diff Jumlah Asset & Diff Jumlah Tenaga Kerja & Diff Omset \\
\hline Arsitektur & 54.99 & -788529123.13 & -30.54 & 0.00 \\
\hline Desyen & 40.32 & -958155276.62 & -24.47 & 0.00 \\
\hline Fesyen & 100.00 & 0.00 & 0.00 & 0.00 \\
\hline Kerajinan & 28.84 & -7243140987.05 & -328.18 & 0.00 \\
\hline Musik & 100.00 & 0.00 & 0.00 & 0.00 \\
\hline Pasar Barang Seni & 39.41 & -20304304044.63 & -13.94 & 0.00 \\
\hline Penerbitan dan Percetakan & 22.65 & -4467036202.53 & -194.30 & 0.00 \\
\hline Periklanan & 21.04 & -3894235239.42 & -11.84 & 0.00 \\
\hline Permainan Interaktif & 4.18 & -295799628.08 & -2.87 & 0.00 \\
\hline Riset dan Pengembangan & 11.02 & -1250278940.03 & -24.02 & 0.00 \\
\hline Televisi dan Radio & 33.82 & -3773361227.34 & -13.24 & 0.00 \\
\hline Video, Film, dan Fotografi & 17.74 & -2646613203.16 & -37.84 & 0.00 \\
\hline Sum
\end{tabular}

Sumber : Hasil Pengolahan Data dengan Software Frontier Versi 4.1, Tahun 2019

Berdasarkan tabel di atas, industri kreatif yakni arsitektur, desyen, kerajinan, pasar barang seni, penerbitan dan percetakan, periklanan, permainan interaktif, riset dan pengembangan, televisi dan radio serta video, film, dan fotografi belum mencapai efisien karena nilai actual jumlah asset dan tenaga kerja yang digunakan melebihi dari target yang ditetapkan untuk mencapai omset yang ditetapkan. Langkah yang dapat dilakukan untuk mencapai target yang ditetapkan maka target omset harus ditingkatkan, karena apabila harus mengurangi input yakni jumlah asset dan jumlah tenaga kerja akan menimbulkan persoalan baru. Sedangkan fesyen dan musik menghasilkan nilai target dan actual yang sama baik omset, jumlah asset dan jumlah tenaga kerja. Untuk membuktikan bahwa fesyen dan musik merupakan industri kreatif unggulan Kota Bandung dapat dilihat pada gambar plot efisiensi dimana fesyen dan musik berada di angka 100 persen, sedangkan arsitektur, desyen, kerajinan, pasar barang seni, penerbitan dan percetakan, periklanan, permainan interaktif, riset dan pengembangan, televisi dan radio serta video, film, dan fotografi belum mencapai nilai $100 \%$.

Untuk hasil analisis software Frontier 4.1 menunjukkan bahwa untuk kategori input variabel omset mempunyai sebaran bahwa omset industri fesyen sangat besar dengan jumlah pelaku usaha terbanyak di Kota Bandung, dan mencapai efisiensi yang $100 \%$ karena projected value $=$ actual value, demikian juga untuk industri musik mencapai $100 \%$ efisiensi dengan omset yang lebih kecil sama dengan industri lainnya. Sebagian besar industri kreatif Kota Bandung mempunyai nilai omset yang relatif bagus tetapi efisiensinya yang rendah, karena dibanding investasi. Permodalan/Asset yang tinggi tidak sebanding dengan omset yang dihasilkan, demikian juga dengan jumlah tenaga kerja yang banyak tetapi produktifitasnya rendah sehingga omsetnya rendah.

Berdasarkan proses pengolahan data, bahwa yang terkumpul data asset yang dimiliki oleh usaha yang merupakan nilai modal, bangunan dan peralatan, sedangkan data tenaga kerja yang menunjukkan eksistensi SDM yang dimiliki sebagai operator dan pengelola usaha, serta data nilai omset yaitu nilai penjualan yang diterima oleh industri kreatif per hari nya. Dengan keterbatasan data hasil survei primer, maka model DEA yang dibentuk adalah bagaimana asset yang dimiliki dan tenaga kerja yang digunakan terhadap omset yang dihasilkan, dimana pada prinsipnya faktor input yang lebih banyak variabelnya akan memberikan efisiensi relatif yang lebih presisi seperti adanya data produksi, data modal, data biaya bahan baku, data investasi, dan variabel outputnya data penjualan, serta data pangsa pasar. 
Correlation: 0.66

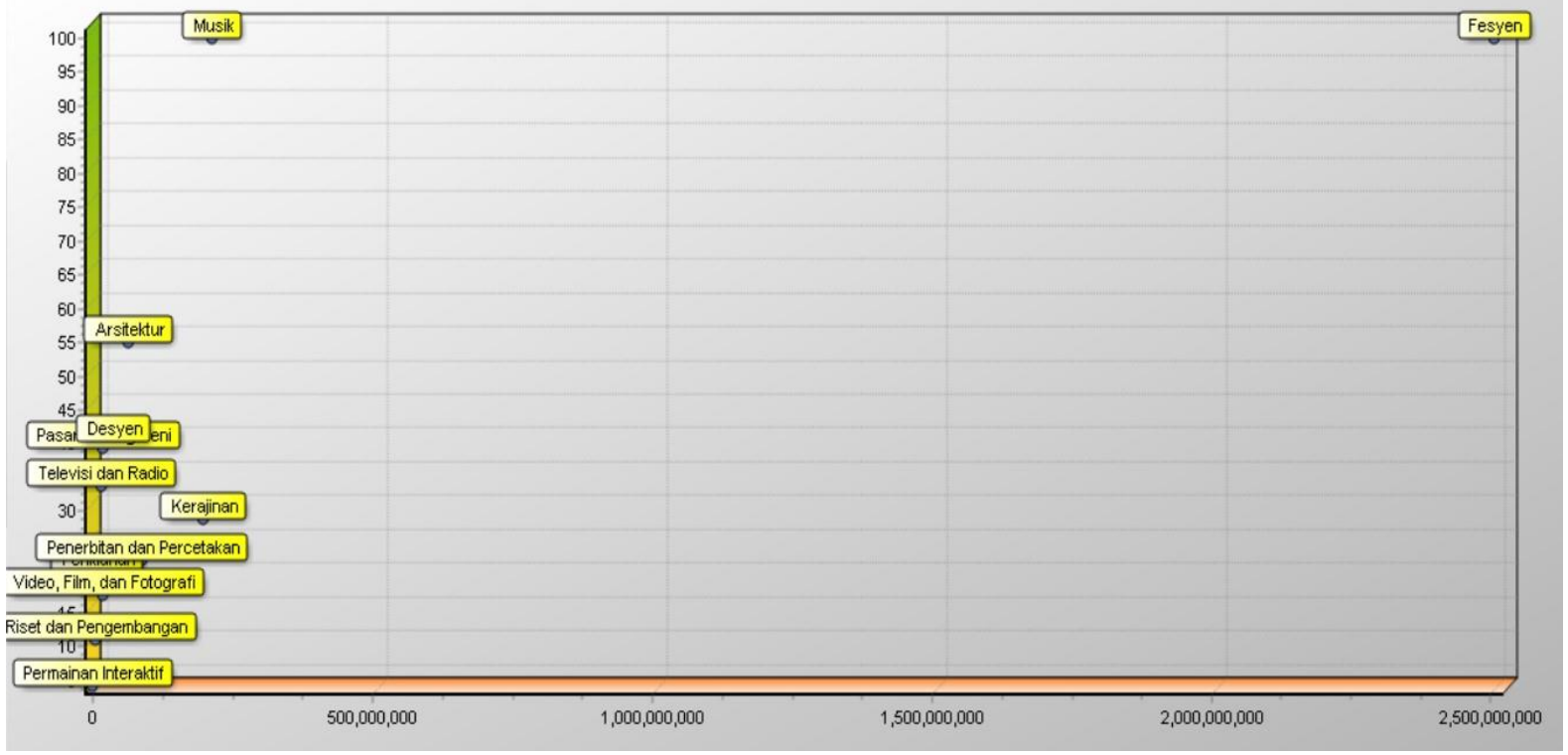

Sumber : Hasil Pengolahan Data dengan Software Frontier Versi 4.1, Tahun 2019

Gambar 5. Plot Efisiensi Omset Industri Kreatif Kota Bandung

Efisiensi adalah kemapuan untuk mencapai suatu hasil yang diharapkan (output) dengan mengorbankan (input) yang minimal. Suatu kegiatan telah dikatakan efisien jika pelaksanaan kegiatan telah mencapai sasaran (output) dengan pengorbanan (input) terendah, sehingga efisiensi dapat diartikan sebagai tidak adanya pemborosan (Nicholson, 2002 : 427) dalam Raihan Hanafi (2017).

Menurut Soekartawi (1994:218) dalam Raihan Hanafi (2017), efisiensi terbagi menjadi dua jenis yaitu efisiensi teknis merupakan efisiensi yang menghubungkan antara produksi yang sebenarnya dan produksi maksimum. Suatu penggunaan faktor produksi yang dipakai menghasilkan produksi yang maksimum. Efisiensi teknis tercapai bila pengusaha mampu menglokasikan faktor produksi sedemikian rupa sehingga hasil yang tinggi dapat dicapai. Sedangkan efisiensi harga menerangkan hubungan antara biaya dan output. Efisiensi harga tercapai jika suatu perusahaan mampu memaksimalkan keuntungan dengan menyamakan Nilai Produksi Marjinal (NPM) setiap faktor produksi dangan harganya. Efisiensi harga atau sering disebut pula allocative efficiency, sebenarnya belum dapat dipakai sebagai ukuran yang kuat (grid) dalam menggambarkan efisiensi, karena itu perlu dilihat juga efisiensi teknis dan efisiensi ekonomi.

Interpretasi dari hasil pengolahan data berdasarkan Software Frontier Versi 4.1 menunjukkan bahwa efisiensi 100\% dicapai oleh industri kreatif musik dan fesyen, yang dianggap dengan sumber daya asset yang dimiliki dan sumber daya manusia tenaga kerja mampu menghasilkan omset yang sepadan atas inputnya, sedangkan efisiensi beberapa industri kreatif lain relatif rendah, nilai asset dan sumber daya manusia yang banyak hanya menghasilkan omset yang rendah atau tidak sepadan.

Fesyen merupakan salah satu subsektor yang dominan dalam memberikan kontribusi ekonomi, selain kerajinan. Fesyen menjadi lokomotif dalam perkembangan industri kreatif nasional. Kontribusi fashion sejauh ini mengungguli kontribusi jenis industri kecil lainnya, baik dalam nilai tambah, tenaga kerja, jumlah perusahaan, maupun ekspornya. Nilai tambah yang dihasilkan fashion berturut-turut sebesar 44,3 persen dari total kontribusi sektor industri kreatif dengan penyerapan tenaga kerja yakni rnencapai 54,3 persen dengan jumlah usaha sebesar 51,7 persen. Faktor penyebab fesyen mendominasi dalam industri kreatif karena populasinya menyebar di seluruh wilayah Indonesia. (Kementrian Perindustrian, 2013) dalam Nidia Zuraya (2013).

Kedepan, peluang industri fesyen khususnya industri fesyen muslim untuk berkembang sangat besar. Hal ini disebabkan karena perkembangan jumlah umat muslim dunia terus mengalami peningkatan. Menurut Airlangga Hartanto (2019) dalam Wilfridus Setu Embu (2019), konsumsi fesyen muslim dunia mencapai USD 270 miliar, terus meningkat dengan laju pertumbuhan 5 persen dan pada tahun 2023 diproyeksikan akan mencapai USD 361 miliar. Sementara konsumsi fesyen muslim 
Indonesia senilai USD 20 miliar dengan laju pertumbuhan 18,2 persen per tahun. Hal ini menunjukkan peluang pasar fesyen muslim global maupun domestik sangat besar dan harus diisi oleh industri fesyen muslim tanah air. Sesuai data dari The State of Global Islamic Economy Report 2018/2019 Indonesia merupakan runner up negara yang mengembangkan fesyen muslim terbaik di dunia setelah Uni Emirat Arab. Pangsa pasar fesyen muslim terbesar adalah negara-negara OKI yaitu mencapai USD 191 miliar, sementara Indonesia baru mengisi USD 357,6 juta.

Sementara itu, menurut Bekraf (2019), musik merupakan industri kreatif yang cukup menjanjikan dalam dunia showbiz. Besarnya minat dan antusiasme para musisi muda untuk terjun ke dalam bidang ini menunjukkan bahwa musik punya potensi menjadi industri yang lebih besar. Walaupun industri musik punya potensi yang sangat besar, namun beberapa pelaku melihat permasalahan yang harus segera diselesaikan yakni pembajakan yang masih marak sehingga menyebabkan perkembangan industri musik di Indonesia terhambat. Pembajakan menyebabkan turunnya kualitas dan kuantitas produksi, menurunnya apresiasi masyarakat terhadap musik, dan turunnya minat investasi di bidang ini. Sehingga diperlukan berbagai fasilitas untuk melindungi industri musik salah satunya perlindungan HKI yang dapat mengurangi pembajakan.

Perkembangan industri banyak dipengaruhi oleh beberapa faktor yang memberikan dampak kepada pertumbuhannya dimasa yang akan datang. Faktor produksi merupakan salah satu faktor dalam menghasilkan suatu produk baik fisik maupun jasa. Kegiatan produksi membutuhkan sumber daya yaitu : bahan baku, permesinan, bahan penunjang, tenaga kerja, dan energi (bahan bakar dan listrik). Banyak industri mengalami kebangkrutan karena meningkatnya biaya produksi, sedangkan omset atau penjualan tidak mengalami peningkatan, berdampak kepada penurunan keuntungan usaha. Jumlah tenaga kerja banyak tetapi kurang memberikan kinerja dan output yang maksimum, sehingga pemborosan biaya dengan pembayaran gajih/upah.

Kondisi efisiensi dari industri akan mempengaruhi kepada keberlanjutan usaha kedepan, banyak industri yang gulung tikar karena biaya lebih besar dari pendapatan, semakin efisien usaha akan memperpanjang nafas bisnis tersebut, meskipun faktor eksternal juga ikut mempengaruhi kepada keberlangsungan usaha seperti pajak, inflasi, kenaikan harga bahan baku, tenaga kerja, transportasi dan logistik.

\section{KESIMPULAN}

Berdasarkan hasil penelitian dan pembahasan yang dilakukan, maka kesimpulan hasil penelitian adalah industri kreatif unggulan Kota Bandung yang efisien yaitu industri fesyen dan industri musik dengan tingkat efisiensi sebesar $100 \%$. Industri fesyen terpilih dikarenakan investasi dan permodalan serta tenaga kerja yang digunakan mampu menghasilkan omzet yang besar, dimana produk fesyen Kota Bandung meliputi pakaian jadi, kaos, produk dasar kain lainnya yang menjadi salah satu ikonik Kota Bandung dan menjadi daya tarik lokal maupun dari luar Kota Bandung untuk berbelanja di pusat perbelanjaan modern maupun tradisional di Bandung. Sedangkan industri musik terpilih karena dengan modal investasi lebih kecil daripada industri fesyen dan relatif sama dengan industri kreatif lainnya, menghasilkan omset yang sepadan dengan permodalan dan tenaga kerja yang digunakan, dimana pendapatan dari produk lagu, theme song, musik tradisional dan modern, peralatan musik (angklung, gitar) dan event musik lokal dan nasional memberikan kontribusi terhadap omset industri musik Kota Bandung.

\section{REFERENSI}

Akbar Gunawan, Putiri Bhuana Katili, Mukti Lestari. 2017. Pemetaan Potensi Industri Kreatif Unggulan Untuk Meningkatkan Pertumbuhan Ekonomi (Studi kasus industri kreatif di Kota Cilegon). Journal Industrial Servicess Vol. 3 No. 1b Oktober 2017.

Andrew Filardo, Nugroho Priyo Negoro, dan Aang Kunaifi. 2017. Penerapan Data Envelopment Analysis dalam Pengukuran Efisiensi Retailer Produk Kendaraan Merek Toyota. JURNAL SAINS DAN SENI ITS Vol. 6, No. 1, (2017) ISSN: 2337-3520 (2301-928X Print).

Badan Ekonomi Kreatif. 2019. Musik. Bekraf. Jakarta. Dapat diakses pada https://www.bekraf.go.id/subsektor/page/musik.

Dina Mellita, dan Deni Erlansyah. 2014. Pemetaan Industri Kreatif dalam Meningkatkan Pertumbuhan Ekonomi Kawasan Urban di Kota Palembang" : Prosiding Seminar Nasional \& Call For Paper. 
Economic Globalization Trend \& Risk Developing Country. Fakultas Ekonomi Universitas Kristen Maranatha. Bandung.

Dzikri Prakasa Putra, M.Ridha Alhamdani, Ivan Gunawan. 2013. Pusat Industri Kreatif di Kota Pontianak. Jurnal Online Mahasiswa Arsitektur "Langkau Betang". Volume I/Nomor 1/Maret 2013.

G. E. Battese and T. J. Coelli. 1995. A Model for Technical Inefficiency Effects in a Stochastic Frontier Production Function for Panel Data. Empirical Economics (1995) 20:325-332. PhysicaVerlag, Hidelberg.

Higgs, P. and Cunningham, S. 2008. Creative Industries Mapping: Where have we come from and where are we going?. Creative Industries Journal 1(1). 7-30;

Nidia Zuraya. 2013. Fesyen Sumbang 44,3 Persen Pertumbuhan Industri Kreatif. Republika.co.id. Jakarta. Dapat diakses pada https://republika.co.id/berita/ekonomi/makro/13/06/27/mplpwffesyen-sumbang-443-persen-pertumbuhan-industri-kreatif.

Nusarina Yuliastuti. 2019. Bekraf : Perkembangan Industri Kreatif Cukup Pesat. antaranews.com. Jakarta dapat diakses pada https://www.antaranews.com/berita/831360/bekraf-perkembanganindustri-kreatif-cukup-pesat.

Raihan Hanafi. 2017. Analisis Efisiensi Penggunaan Faktor Produksi Pada Industri Kecil Dan Menengah Furnitur Di Kota Pekanbaru. JOM Fekon, Vol. 4 No. 1 (Februari) 2017.

Roodhouse, S. 2008. The scope of Creative Industries Journal (CIJ) in Roodhouse, S.; Hayes, D. \& Harper, G. (Eds.) Creative Industries Journal 1(1).1.

Wilfridus Setu Embu. 2019. Menperin Beberkan Peluang Industri Fesyen Indonesia. Liputan6.com. Jakarta. Dapat diakses pada https://www.liputan6.com/bisnis/read/3954687/menperinbeberkan-peluang-industri-fesyen-indonesia. 